\title{
DYNAMICS OF FINANCIAL DEVELOPMENT, ECONOMIC GROWTH, AND POVERTY ALLEVIATION: THE INDONESIAN EXPERIENCE
}

Sovia Dewi, M. Shabri Abd. Majid, Aliasuddin, Salina Kassim

\begin{tabular}{|c|c|}
\hline \\
\hline \multicolumn{2}{|l|}{$\begin{array}{l}\text { Although the poverty rate in Indonesia has been dec } \\
\text { is slowing down. In order to achieve its poverty reduc } \\
\text { ment has stepped up efforts to enhance the contrib } \\
\text { This study aims to empirically explore the interlinka } \\
\text { reduction in Indonesia. Focusing on annual data cc } \\
\text { the Autoregressive Distributed Lag (ARDL) cointegra } \\
\text { tween the variables. The study found that there is } \\
\text { economic growth, and poverty reduction in Indones } \\
\text { from the financial sector to poverty reduction and c } \\
\text { poverty reduction. Therefore, policies to ensure the c } \\
\text { way in promoting the economy, creating employme } \\
\text { eradication. }\end{array}$} \\
\hline \multirow{3}{*}{$\begin{array}{l}\text { Keywords: Financial sector, economic growth, } \\
\text { income inequality, poverty alleviation, ARDL, } \\
\text { Indonesia } \\
\text { JEL Classification: C32;G21;I32;O1;O5 } \\
\text { INTRODUCTION } \\
\text { The relationship between the financial sector, eco- } \\
\text { nomic growth, and poverty reduction has captured } \\
\text { the interest of both researchers and policymakers } \\
\text { since the discrepancies between theory and the re- } \\
\text { sults of practical policy implementation with regard } \\
\text { to the interplay of these factors have been rather glar- } \\
\text { ing. Theoretically, the financial sector has a strong } \\
\text { link with the real economy through the provision of } \\
\text { financial resources to the factors of production, stim- } \\
\text { ulating the production of real output, increasing job }\end{array}$} & \\
\hline & \\
\hline & $\begin{array}{l}\text { liasuddin, PhD } \\
\text { aculty of Economics and Business, } \\
\text { yiah Kuala University, Indonesia } \\
\text {-mail: aliasuddin@fe.unsyiah.ac.id }\end{array}$ \\
\hline
\end{tabular}


opportunities, and reducing poverty levels. Ironically, in many cases, countries experiencing rapid financial development have exhibited greater income inequality, suggesting that efforts to reduce poverty may not have been realized despite rapid development in the financial sector.

Indonesia has experienced encouraging economic growth at an average of $5.64 \%$ per annum over the period of 2010-2015, supported by the stability of the financial sector; however, the country has recorded a lower ability to reduce the level of poverty. According to the Central Statistics Agency of Indonesia (2017), a $1 \%$ increase in economic growth was targeted to reduce the poverty level by $0.116 \%$ over the period 2010-2015; in reality, it only reduced the poverty level by a mere $0.059 \%$.

Understanding the relationship between financial development and poverty alleviation is of particular importance for Indonesia. Over the last decade, the financial sector has become a locomotive of growth for the real sector through the accumulation of capital and technological advancement. The contribution of the financial sector to national economic development, as indicated by the ratio of money supply to the Gross Domestic Product (GDP), has increased by $15.89 \%$ from $21.41 \%$ in 2009 to $37.3 \%$ in 2013 . This rapid process of growth in the centrality of the financial sector is also reflected in the increase in the ratio of domestic credit to the private sector from $36.96 \%$ in 2009 to $45.64 \%$ in 2013 (Statistical Year Book of Indonesia 2014).

As a result of a higher contribution of the financial sector to the national economy, the rate of decline of the poverty rate was in the range of $1.27 \%-1.78 \%$ from 2004 to 2009. However, since 2010 onwards, the rate has slowed by only $0.4 \%-0.8 \%$ (Central Statistics Agency of Indonesia 2011). More importantly, the decline in the poverty rate has not been accompanied by an equitable distribution of income as indicated by the country's Gini coefficient, which increased from 0.37 in 2009 to 0.41 in 2014 (Bappenas 2015). The increase in the Gini coefficient is an alarming sign, indicating that income inequality in Indonesia has actually widened. These facts show that poverty remains a major issue in Indonesia. Overall, the number of people living below the national poverty line in 2014 remained high at $10.96 \%$ (Central Statistics Agency of Indonesia 2015). Indonesia has failed to achieve its target of a nationwide poverty reduction level to $7.55 \%$ by 2015 , as set by the Millennium Development Goals (MDGs) in 2000. With its large population of 258.7 million people in 2015 (Bappenas 2017), it is estimated that 19.53 million Indonesians are living under the national poverty line.
As Indonesia aspires to achieve the status of a developed country by the year 2040, it is apparent that a concerted effort to eradicate poverty in Indonesia is urgently needed. Since the various economic development programs undertaken to alleviate poverty will only be effective with the support of resource mobilization, substantial developments in the financial sector are expected to attract these resources. Several multi-lateral agencies, including the World Bank, Asian Development Bank, and International Monetary Fund have long been supporting the development of the financial sector in Indonesia to attract foreign resources as part of broader efforts to alleviate poverty. On the domestic front, local authorities such as the Central Bank of Indonesia - Bank Indonesia have consistently made various efforts to provide a conducive environment for financial sector growth.

Previous empirical studies on the relationship between the financial sector and poverty alleviation documented mixed findings. The majority recorded a positive contribution from financial sector development on poverty reduction (Beck et al. 2007; Shahbaz et al. 2015), while others suggested otherwise, with financial sector growth seemingly causing the poverty level to increase (Dhrifi 2014). Additionally, many studies found a strong unidirectional causal effect from the financial sector on poverty alleviation (Jalilian and Kirkpatrick 2005; Odhiambo 2010a), whereas several other studies revealed a unidirectional causal effect on poverty reduction from financial sector development (Uddin et al., 2012; Perez-Moreno 2011), a bidirectional effect between the financial sector and poverty reduction (Beck et al. 2007; Uddin et al. 2012; Abosedra et al. 2016), and no causal effect between the financial sector development and poverty reduction (Perez-Moreno 2011; Uddin et al. 2014).

While the majority of the abovementioned studies were conducted in countries in Latin America, Africa, Asia, none has focused on the Indonesian case. Additionally, these studies investigated causalities between the financial sector and poverty reduction, but no attention was given to the relative strengths of the financial sector in reducing poverty and the extent to which poverty levels are caused by changes in financial sector development. This motivated the present study, which aims to provide the latest empirical evidence on the contribution of financial sector development to poverty reduction, particularly in the context of Indonesia.

Given that poverty reduction has been a major issue in Indonesia, to the best of our knowledge this study is among the first attempts to provide empirical evidence on the financial sector-poverty reduction nexus in Indonesia. It also tries to fill in an existing gap 
in the literature by exploring the causalities between the financial sector and poverty reduction, assessing the relative strengths of the financial sector in reducing poverty, as well as understanding the impact of the financial shocks on the poverty level. Specifically, the study aims to address five main research questions: (i) what is the nature of the relationship between financial development, economic growth and poverty reduction?; (ii) is there a long-term relationship between the financial sector, economic growth, and poverty alleviation?; (iii) is there a causal relationship between the financial sector, economic growth, and poverty?; (iv) how do shocks in the financial sector and economic growth affect poverty reduction?; and $(v)$ what are the relative strength of impacts of the financial sector and economic growth changes to the poverty level?

By further probing into the issues concerning the financial sector and poverty reduction comprehensively, the findings of this study are expected to provide important inputs for the relevant authority to formulate policies to ensure a meaningful contribution from the financial sector that could ultimately help to alleviate poverty. The study also makes a methodological contribution to the literature in terms of using vigorous investigation techniques in arriving at robust and possibly conclusive empirical evidence for the financial development-poverty reduction nexus in Indonesia.

The remaining part of this paper is organized as follows. The next section reviews related literature on the relationship between the financial sector and poverty reduction. The data and methods used in the empirical testing are described in the subsequent section, followed by a description and interpretation of the results, and the final section offers conclusions on the main findings and provides recommendations for policy-makers and possible further studies.

\section{LITERATURE REVIEW}

According to Levine (2005), the financial sector plays six basic functions in the economy, namely: (i) mobilization of savings; (ii) management of risks; (iii) gathering of information about investment opportunities; (iv) exerting control for companies; (v) facilitating transactions; and (vi) promoting the exchange of goods and services. An efficiently functioning financial sector facilitates the process of financial deepening, leading to a well-developed financial sector, which in turn is highly critical to boosting economic growth. More importantly, the evenly distributed growth of the financial sector benefits society overall, regardless of their level of income, and ultimately contributes towards better income equality, thereby reducing poverty.

The contribution of the financial sector to economic development and poverty reduction has been of major interest among researchers and policy-makers in the last few decades. Despite this, existing studies on the relationship between the financial sector and poverty alleviation have been found to be largely inconclusive. Some studies recorded a positive contribution by the financial sector development on poverty reduction (see, for example, Beck et al. 2007; Shahbaz et al. 2015), while others have found otherwise, including cases where financial sector development was found to result in an increase in the poverty level (Dhrifi 2014).

Jalilian and Kirkpatrick (2005) suggested that the development of the financial sector could boost the chances of the poor to access official financing by overcoming the failures of the financial market, owing to the fact that asymmetric information could lead to a high cost of borrowing and limit the accessibility of borrowers to the credit market. With the development of the financial sector, the poor are able to raise capital to start a micro-business that generates greater employment opportunities, increase incomes, and ultimately reduce poverty. Further development of the financial sector would result in a trickle-down effect to the poor through the higher availability of job opportunities, resulting in a better distribution of income. Intuitively, the development of the financial sector has a direct impact on real economic activity and improves the living standards of the poor.

Beck et al. (2007) examined the relationship between the financial sector, inequality, and poverty reduction in Peru using data from 1960 to 2005 and found a significant impact of financial sector development on poverty reduction and subsequently helped to reduce income inequality. The study recorded that about $40 \%$ of the long-run impact of financial sector development on the income growth of the poorest quintile was attributable to reductions in income inequality, whereas about $60 \%$ was contributed by the impact of financial sector development on economic growth. Financial sector development reduced the number of the population earning less than 1 USD a day, emphasizing the pivotal role of financial institutions for the poor. At the micro level, Smajic and Ermacora (2007) investigated whether female-headed households (FHHs) were over-represented among the poor as compared to male-headed households (MHHs) in Bosnia and Herzegovina in 2001. Using a consumption dimension to measure poverty, the study documented that there 
was no significant difference in the annual per capita consumption between the two groups, implying that the $\mathrm{MHH}$ s were not better-off than the FHHs in terms of annual per capita consumption in the country. The finding implied that the poverty alleviation program should not take into account headship while targeting poor households. To combat poverty, the government should provide financial support or integrate the poor segment of the population, irrespective of their headships.

Several cross-country studies have shown evidence on the positive impact of the financial sector growth to the income level of the poor. Odhiambo (2009a and 2009b) focused on the cases of several countries in South Africa and found evidence that financial sector development and economic growth lead to poverty reduction. There is a unidirectional causality running from poverty reduction to financial sector development when a monetization variable is used as a proxy for measuring financial sector development. However, when the ratio of credit to the private sector and domestic money bank assets are used as proxies for financial development, the study recorded a unidirectional causality running from financial sector development to poverty reduction. The unidirectional causality from the financial sector to poverty reduction is also supported by a later study by Odhiambo (2010a) for the case of Kenya during the period 1968-2006 using cointegration and errorcorrection modelling. Additionally, the study found a unidirectional causality from financial sector development to savings and a bidirectional causality between savings and poverty reduction.

For the case of China, Ho and Odhiambo (2011) explored the financial development - poverty reduction nexus over the period 1978-2008 using an ARDL approach to cointegration. The study showed that the nature of the causal relationship between the investigated variables would critically depend on the proxy adopted to measure financial development. A bidirectional causality between financial development and poverty reduction is recorded when the ratio of domestic credit to the private sector is used as a proxy for financial development, while a unidirectional causality from poverty reduction to financial development is documented when the broad money supply is used as a proxy for measuring financial development. These findings imply that continuous efforts to combat poverty in China have contributed positively to further developing the financial sector in the long run.

Perez-Moreno (2011) also recorded mixed findings due to different proxies used to measure financial development. Using the Granger causality approach, the study empirically explored the causal interlinks between financial development and poverty rate in 35 developing countries during the 1970s-1980s. Two proxies for measuring financial development were used, namely the ratio of liquid assets to national income and the ratio of quasi-money to the national economy. Using the former proxy, financial development was found to Granger cause the poverty reduction, while using the latter proxy the study found no causal relationship between the variables. The study concluded that the limited access of the poor in obtaining credit from the financial sector has caused the poverty level to increase.

In the specific context of Bangladesh, Uddin et al. (2012) conducted an empirical investigation on the relationship between banking sector development and poverty reduction during the period from 1976 to 2010. By adopting an ARDL approach, the study documented that there was a long-run relationship between banking sector development and poverty reduction. From a long-run perspective, the study found that poverty reduction is found to be the only variable explaining banking sector development. In a later study, Uddin et al. (2014) explored the causality between financial deepening, economic growth and poverty reduction using quarterly data over the period 1975-2011 in Bangladesh, and found evidence of a long-run relationship between financial development, economic growth, and poverty reduction. Economic growth was also found to Granger cause financial development and poverty reduction. This finding of unidirectional causality running from economic growth to financial development supported a demand-side hypothesis where higher economic activities result in greater demand for financial services, thus giving further support to the financial sector.

Using data from 22 low-income countries, 37 middle-income countries, and 30 high-income countries, Dhrifi (2014) found that the development of the financial sector led to an increase in economic growth and poverty reduction. The study found GDP per capita and income inequality have a positive and significant effect on poverty rate, while the development of the financial sector has a significant negative effect on poverty reduction. This result is contrary to the economic theory that development of the financial sector yields a significant and positive effect on the poverty level. The results can be attributed to two reasons: first, the financial sector in low-income countries still has limited access to finance in the long term that would reduce the ability to finance local credit, and second, the lack of innovative financial instruments is mainly targeted at the informal sector. 
Based on annual time series data during the period 1970-2010, Akinboade and Kinfack (2014) investigated the financial sector-poverty relation in South Africa using a Vector Error Correction Model (VECM). The study found long-run relationships between per capita household expenditure for food, per capita income, and financial sector development. In the short run, the study documented that per capita income improved per capita expenditure on education, while financial development reduced spending on education. However, the study found no significant relationships among financial sector development, household expenditure, and economic growth, both in the short and long run. Intuitively, effective efforts to promote the financial sector development should be done through enhancing per capita income and improving household expenditure on the basic needs of poor segments of the country's population.

In Egypt, the development of the financial sector and its inter-temporal relationship with poverty reduction is investigated by Abosedra et al. (2015). By applying the ARDL regression on quarterly data for the period from 1975 to 2011, the study found a long-run relationship between financial deepening, economic growth, and poverty reduction when domestic credit to the private sector was used as a proxy for financial sector development. In addition, the study documented a short-run, bi-directional causal relationship between the financial sector and poverty when poverty is measured by the infant mortality rate, implying that the financial sector served as a direct channel for the poor to access financial services and expand their economic capacity. Ultimately, the development of the financial sector contributes to poverty reduction through a well-distributed access to financial capital and more balanced economic opportunities for all segments of the society.

By utilizing the ARDL technique and VECM, Shahbaz et al. (2015) investigated financial development and income inequality in Iran during the period of 1965-2011. The study confirmed the existence of a long-run equilibrium between the variables. Additionally, the study suggested that financial development, price stability, and globalization reduced income inequality, but that economic growth increased income inequality. These findings implied that to reduce income inequality, policy-makers should make economic growth more fruitful for the poorest segments of the population and direct the financial sector to grant wider access to the financial resources of poor persons at a cheaper price.

Furthermore, Miled and Rejeb (2015) explored the contribution of 596 microfinance institutions to poverty alleviation across 40 developing countries in the year 2011 and 1,132 microfinance institutions in 57 developing countries for the years 2005 and 2011. The study revealed that countries with higher microfinancial institution gross loan portfolios per capita had lower poverty levels and higher levels of income per capita. Additionally, price stability and economic growth contributed to poverty. These findings proved the affirmative role played by the micro-financial institutions in poverty reduction, provided that the country experienced steady economic growth and price stability.

Based on the literature review above, we noticed that empirical evidence on the role of financial sector development in poverty reduction has been mixed. Some studies have found a positive role by the financial sector in the context of poverty reduction, while some have found otherwise. Additionally, those studies also documented different causal directions between financial sector development and poverty alleviation. Motivated by these inconclusive findings and to provide the latest and comprehensive empirical findings by using a longer data period and rigorous empirical models, this study tries to fill the gaps in the existing literature on the causal relationships between the financial sector and poverty in Indonesia.

\section{DATA AND EMPIRICAL MODELS Data}

This study uses annual time series data for the period 1980-2015 gathered from several sources, namely the Economic and Financial Statistics Indonesia of the Central Statistics Agency of Indonesia (2016), Central Bank of Indonesia (2016), the World Bank (2016), and the Statistical, Economic, and Social Research and Training Centre for Islamic Countries (SESRIC 2016).

Apart from poverty level and financial sector development, economic growth is also included in the model as a control variable. In this study, poverty (LPOV) is measured by per capita household consumption expenditure in Indonesian Rupiah (IDR), collected from the Central Statistics Agency of Indonesia (2016). Financial sector development (FD) is measured by two proxies: first, the money supply (LM2), gathered from the Central Bank of Indonesia (2016), while the second is the ratio of domestic credit to the private sector to GDP (CR), which is collected from the World Bank (2016). Finally, economic growth (LPDB) is measured by per capita income gathered from SESRIC (2016). With the exception of CR, all of the other variables are estimated in natural logarithmic form. 


\section{Empirical models}

To empirically explore the relationship between poverty and the financial sector, the following general empirical model is estimated:

$$
L P O V_{t}=a_{0}+\beta_{1} F D+\beta_{2} L P D B+\varepsilon_{t}
$$

Since the measurement of the financial sector (FD) uses two proxies, i.e., the money supply (LM2) and the ratio of domestic credit to private sector to GDP, Equation (1) is further split into the following:

$$
\begin{aligned}
& L P O V_{t}=a_{0}+\beta_{1} L M 2+\beta_{2} L P D B+\varepsilon_{t} \\
& L P O V_{t}=a_{0}+\beta_{1} C R+\beta_{2} L P D B+\varepsilon_{t} \ldots
\end{aligned}
$$

where LPOV is the poverty level, FD is the financial sector, LM2 is the money supply, CR is the credit ratio, LPDB is the economic growth, and $\varepsilon$ is the error term.

Before the data are further analyzed, Augmented Dickey-Fuller (ADF) and Phillips-Perron (PP) unit root tests were conducted to ensure the stationary of data and to arrive at the robust findings. After confirming all data were stationary, the next step was to examine the long-run equilibrium between the financial sector and poverty using the ARDL approach to cointegration. According to Samargandi et al. (2014), the ARDL model was very useful in the empirical economic analysis due to the dynamics of economic theory at the time. In addition, the use of ARDL has several advantages, namely: (1) it can be used to estimate variables integrated of order zero, $I(0)$, integrated of order one, $I(1)$ or fractionally integrated (Pesaran and Pesaran 1997; Bahmani-Oskooee and Ng 2002), and thus avoids problems resulting from non-stationary time series data (Laurenceson and Chai 2003); (2) it takes sufficient numbers of lags to capture the data generating process in a general-to-specific modelling framework (Laurenceson and Chai 2003); (3) it can generate endogeneity and unbiased estimated coefficients; and (4) its finding is consistent and robust for a smaller sample size of cointegration analysis. Since the sample size of our study is small, this provides more of a basis to adopt this approach.

Based on Equation 1, further empirical models of the ARDL bound testing approach to cointegration were estimated:

$$
\begin{aligned}
& \Delta L P O V_{t}=\alpha_{01}+\sum_{i=1}^{n} \alpha_{11} \Delta\left(L P O V_{t-i}\right) \\
& +\sum_{i=1}^{n} \alpha_{12} \Delta\left(L M 2_{t-i}\right)+\sum_{i=1}^{n} \alpha_{13} \Delta\left(L P D B_{t-i}\right)+ \\
& \beta_{11} L P O V_{t-1}+\beta_{12} L M 2_{t-1}+\beta_{13} L P D B_{t-1}+\varepsilon_{1 t} \ldots
\end{aligned}
$$

$$
\begin{aligned}
& \Delta \operatorname{LPOV}_{t}=\alpha_{01}+\sum_{i=1}^{n} \alpha_{11} \Delta\left(\operatorname{LPOV}_{t-i}\right) \\
& +\sum_{i=1}^{n} \alpha_{12} \Delta\left(C R_{t-i}\right)+\sum_{i=1}^{n} \alpha_{13} \Delta\left(L P D B_{t-i}\right)+ \\
& \beta_{11} L P O V_{t-1}+\beta_{12} C R_{t-1}+\beta_{13} L P D B_{t-1}+\varepsilon_{1 t} \cdots
\end{aligned}
$$

$\Delta L M 2_{t}=\alpha_{02}+\sum_{i=1}^{n} \alpha_{21} \Delta\left(L M 2_{t-i}\right)$

$+\sum_{i=1}^{n} \alpha_{22} \Delta\left(\operatorname{LPOV}_{t-i}\right)+\sum_{i=1}^{n} \alpha_{23}\left(L P D B_{t-i}\right)+$

$\beta_{21} L M 2_{t-1}+\beta_{22} L P O V_{t-1}+\beta_{23} L P D B_{t-1}+\varepsilon_{2 t} \ldots \ldots$

$\Delta C R_{t}=\alpha_{02}+\sum_{i=1}^{n} \alpha_{21} \Delta\left(C R_{t-i}\right)$

$+\sum_{i=1}^{n} \alpha_{22} \Delta\left(\operatorname{LPOV}_{t-i}\right)+\sum_{i=1}^{n} \alpha_{23}\left(L P D B_{t-i}\right)+$

$\beta_{21} C R_{t-1}+\beta_{22} L P O V_{t-1}+\beta_{23} L P D B_{t-1}+\varepsilon_{2 t}$

$\Delta L P D B_{t}=\alpha_{03}+\sum_{i=1}^{n} \alpha_{31} \Delta\left(L P D B_{t-i}\right)$

$+\sum_{i=1}^{n} \alpha_{32} \Delta\left(L P O V_{t-i}\right)+\sum_{i=1}^{n} \alpha_{33}\left(L M 2_{t-i}\right)+$

$\beta_{31} L P D B_{t-1}+\beta_{32} L P O V_{t-1}+\beta_{33} L M 2_{t-1}+\varepsilon_{3 t} \ldots .$.

$\Delta L P D B_{t}=\alpha_{03}+\sum_{i=1}^{n} \alpha_{31} \Delta\left(L P D B_{t-i}\right)$

$+\sum_{i=1}^{n} \alpha_{32} \Delta\left(\operatorname{LPOV}_{t-i}\right)+\sum_{i=1}^{n} \alpha_{33}\left(C R_{t-i}\right)+$

$\beta_{31} L P D B_{t-1}+\beta_{32} L P O V_{t-1}+\beta_{33} C R_{t-1}+\varepsilon_{3 t}$

where LPOV is the poverty level, LM2 and CR are the proxies used to measure financial development, LPDB is economic growth, $a_{1}$ to $a_{3}$ are the short-term coefficients, $\beta_{1}$ to $\beta_{3}$ are the long-term coefficients, $t$ is the year, $i$ is the order lag, and $\varepsilon$ is the error term. The terms with the summation sign correspond to the error correction dynamics, while the terms with $\beta_{i}$ represent the long-run relationship. The hypothesis being tested for the presence of long-run equilibrium between variables in the Equations (2) to (4) is: the null hypothesis: $\mathrm{H}_{0}: \beta_{i 1}=\beta_{i 2}=\beta_{i 3}=0$ (non-cointegrated), while the alternative hypothesis: $\mathrm{H}_{1}: \beta_{i 1} \neq \beta_{i 2} \neq \beta_{i 3} \neq 0$ (cointegrated) in the Equations (2) - (4).

Following Majid and Mahrizal (2007), Majid and Yusof (2009), and Yusof et al. (2011), this study determined the decision to reject or not reject the hypothesis by comparing the calculated F-statistics of the null hypothesis of non-cointegration with Narayan's (2005) 
critical value of F-statistics for a sample size below 100 , since the number of observations of this study was only 35 samples. The null hypothesis is rejected if the computed F-statistics is greater than the upper bound critical value. On the contrary, the null hypothesis is not rejected when the computed F-statistic is smaller than the lower bound critical value. However, if the computed F-statistics falls within the critical value band, the result is inconclusive.

In the next step, after confirming the existence of cointegration, the following bivariate Granger causality models are estimated to detect the direction of the causality bivariate relationship between the financial sector and poverty level, and economic growth and poverty level.

$$
\begin{aligned}
& \Delta L P O V_{t}=\phi+\delta_{1} \Delta L P O V_{t-1}+\ldots+\delta_{p} \Delta L P O V_{t-p} \\
& +\lambda_{1} \Delta L M 2_{t-1}+\ldots+\lambda_{q} \Delta L M 2_{t-q}+\varepsilon_{1 t} \ldots \ldots \ldots \ldots \ldots \ldots . .
\end{aligned}
$$

$+\lambda_{1} \Delta L P D B_{t-1}+\ldots+\lambda_{q} \Delta L P D B_{t-q}+\varepsilon_{2}$

To test for bivariate statistical causality, the F-statistic values of $\delta$ and $\lambda$ are referred. The null hypothesis being tested is the coefficient of $\lambda_{1}=\ldots .=\lambda_{p}$ is equal to zero. If the null hypothesis is not rejected, it can be concluded that the independent variables did not Granger cause the dependent variable. From this test, four pattern directions of interaction between variables could be found: (1) a unidirectional Granger causality from the variable $x$ to the variable $y$; $(2) a$ unidirectional Granger causality from the variable $y$ to the variable x; (3) a bidirectional Granger causality between the variables $x$ and $y$; and (4) no Granger causality between the variables $x$ and $y$.

Next, the Variance Decomposition Analysis (VDA) is estimated to capture the relative strength of the causality among the variables beyond the sample period. Thus, VDA allows us to examine the out-ofsample causality among the variables in the Vector Autoregressive (VAR) model (Majid and Kassim 2009). The model is a system of reduced form dynamic linear equations in which each variable is expressed as a function of serially uncorrelated errors and an equal number of lags of all of the variables in the system (Abdullah 1998; Enders 1995). This model assumes that the contemporaneous correlations of errors across equations are non-zero and therefore there are no contemporaneous explanatory variables in the model. The error terms (also referred to as innovations) can provide a potential source of new information about the movements in a variable during a current period. In order to interpret the economic implications from the VAR model, we use Sims' (1980) innovative accounting procedure. This procedure involves the decomposition of forecast error variance of each variable into components attributable to its own innovations and to shocks of other variables in the system.

Finally, Impulse Response Functions (IRFS) are utilized to evaluate the dynamic relations between the financial sector, poverty, and economic growth. The changes in poverty level might be contemporaneously linked to the financial sector and economic development. This implies that shocks in one variable might work throughout the contemporaneous connection to shocks in other variables. As an isolated innovation in one variable could not be recognized if caused by a contemporaneous connection, the responses of a variable to innovations in another variable could not be satisfactorily signified (Lutkepohl and Poskitt 1991). The general approach to resolving the problem of identification is simply to adopt Sims' (1980) empirical approach by orthogonalizing the innovations utilizing Cholesky factorization. However, the approach necessitates a pre-specified causal ordering of the variables, which turns out to be its main shortcomings. That is to say, the findings from the IRFs analysis might be sensitive to the variables' ordering, particularly once the error terms of contemporaneous correlations in the VAR are found to be high. To resolve this drawback, this study adopted the generalized IRFs proposed by Pesaran and Shin (1998). The generalized IRFs entirely take into consideration the correlation between different historical shocks (Pesaran and Shin 1998). Consequently, they are invariant and unique to the different orderings of equity markets. Another superior feature of the generalized IRFs according to Ewing et al. (2003) is that, as the error configuration is not orthogonalized, the early impact reaction of the poverty level to various shocks can be explored. This characteristic of the generalized IRFs is predominantly handy for examining poverty changes that are commonly characterized by rapid financial sector development transmissions and corrections. 


\section{ESTIMATION RESULTS}

\section{The stationarity test}

The results of stationarity tests based on the ADF and PP are shown in Appendix 1. As observed from Appendix 1, poverty, financial sector, and economic growth are not stationary at level. These variables are stationary at the first difference, or in other words, integrated of order one, I(1).

Confirming that all the variables were stationary, the study further estimates the ARDL Autoregressive Distributed Lag (ARDL) model to ensure the presence of long-term equilibrium among the variables used approach. The findings of F-statistics from the ARDL models (Equation 2 to 4) are reported in Appendix 2.

Overall, the study found that all models were cointegrated, implying the presence of long-term relationships between poverty level, financial sector and economic growth in Indonesia. In other words, these variables were moving in the same direction in the long run. This finding implied that by observing the movement of a variable, one could predict changes in the other variables.

\section{Bivariate Granger causality}

In this study, bivariate Granger causality is conducted to explore the direction or pattern of causality between the financial sector, poverty, and economic growth in Indonesia. As observed from Table 1, the study found a unidirectional causality from the variable of money supply (LM2) to poverty (LPOV), but not vice versa. This suggests that changes in the financial sector have an influence on changes at the poverty level. An increase in money supply as indicated

Table 1: Findings of the Bivariate Granger Causality

\begin{tabular}{|c|c|c|}
\hline $\begin{array}{c}\text { Direction of } \\
\text { Causality }\end{array}$ & $\begin{array}{c}\text { Coefficient of } \\
\text { Causality }\end{array}$ & Conclusion \\
\hline LM2 $\rightarrow$ LPOV & $\begin{array}{c}2.5856^{*} \\
(0.0604)\end{array}$ & Unidirectional \\
\hline LPOV $\rightarrow$ CR & $\begin{array}{c}3.9731^{* *} \\
(0.0120)\end{array}$ & Unidirectional \\
\hline LPDB $\rightarrow$ LPOV & $\begin{array}{c}1.6358^{*} \\
(0.1953)\end{array}$ & Bidirectional \\
\hline LPDB $\rightarrow$ CR & $\begin{array}{c}28.7598^{* * *} \\
(0.0000)\end{array}$ & Unidirectional \\
\hline LM2 $\rightarrow$ LPDB & $\begin{array}{l}2.4470^{*} \\
(0.1042)\end{array}$ & Unidirectional \\
\hline
\end{tabular}

Notes: ${ }^{*},{ }^{* *}$ and ${ }^{* * *}$ indicate the significant levels at the $10 \%$, $5 \%$, and $1 \%$, respectively. Values in the bracket (.) show the probability of the F-test. by the higher level of the price of goods and services in Indonesia has caused household expenditures to decline due to their decrease in real income. The reduction in consumption levels reflects declining levels of public welfare, denoting an increase in the poverty level. These results confirmed the earlier findings by Odhiambo (2010a) in Kenya, Odhiambo (2010b) in Zambia, and Perez-Moreno (2011) in 35 developing countries.

Meanwhile, the study's results suggest that changes in poverty level have no influence on the financial sector. This could be partially due to the decreasing trends of poverty reduction in Indonesia over the period under study, which thus insignificantly increased the per capita income of the poorest segments of the population, and, consequently, failed to promote the financial development. From 2004 to 2009, on average, the poverty rate in Indonesia decreased by $1.53 \%$, but from 2010 onwards, the poverty reduction trend has slowed by an average of $0.6 \%$ (Central Statistics Agency of Indonesia 2011). Poverty still remains a major issue in Indonesia. The poverty level in the country remains high, at $10.96 \%$ in 2014 (Central Statistics Agency of Indonesia 2015), which is far above that of the national target of poverty reduction level of $7.55 \%$ by 2015 (Bappenas 2017).

However, when the financial sector was measured by the ratio of domestic credit to private sector to GDP, the study found a unidirectional causality running from poverty (LPOV) to financial sector development at the $5 \%$ level of significance. This suggests that changes in the level of poverty Granger caused the changes in the ratio of credit provided by the banks to the private sector. When the financial sector in Indonesia provided more access to financial resources to the poor to start up their micro-enterprises, it caused an increase in the per capita income of the poor. Similarly, when the business sector granted more financial resources by the financial institutions to expand their businesses, it provided more job opportunities for the poor to join the labour market in the country. Ultimately, the expansion of employment caused the per capita income of the poor to increase, implying the reduction of the poverty level in the country. These findings supported earlier empirical evidence provided by Odhiambo (2009a and 2009b) in Zambia and South Africa.

Furthermore, economic growth (LPDB) has a twoway causality to poverty reduction (LPOV) at the $10 \%$ level of significance. This suggests that changes in economic growth Granger caused the changes in the poverty level. The economic growth of Indonesia can be attributed mainly to an enhanced private sector that offered more job opportunities to recruit the 
poorest segments of the population into the national labour market, which in turn caused the poverty rate to decline. Similarly, the contribution of the poor who joined the labour market nationwide reduced their poverty level due to their increase in income level would consequently promote national economic development. The Central Statistics Agency of Indonesia (2016) reported that the unemployment rate of Indonesia declined from $9.1 \%$ in 2011 to $5.5 \%$ in 2016. The declining trend of unemployment over the last decades is believed to be one of the important determinants causing poverty reduction, as well as promoting the economic growth of Indonesia. These empirical findings are consistent with studies by Pradhan (2010) in India, Uddin et al. (2012) and Uddin et al. (2014) in Bangladesh, and Abosedra et al. (2015) in Egypt.

Finally, the study's results show that the changes in money supply Granger caused the changes in economic growth at the $10 \%$ significance level. This implies that the price stability of Indonesia over the period of the study promoted national economic growth. The historic inflation rate has shown that although the inflation rate in the country has fluctuated substantially in recent years, it had a tendency to decline over the 1998 - 2017 period, ending at 3.53\% in 2016, as compared to $10.23 \%$ in 2008 (Central Statistics Agency of Indonesia 2016). The declining trend of inflation is believed to be the major factor causing the growth of the Indonesian economy.

The finding of unidirectional causality running from money supply to the economic growth of Indonesia supported the theory of supply leading introduced by Patrick (1966) suggesting the development of the financial sector created opportunities to stimulate economic growth. However, when the financial sector was measured by the credit ratio $(\mathrm{CR})$, the study found a unidirectional Granger causality running from the economic growth to the financial sector, a finding similar to Majid (2008) and Majid and Kassim (2015). In this case, the finding is very much in harmony with the demand-side theory, introduced by Robinson (1952), suggesting that the development of the financial sector was fostered by economic growth. During higher economic growth, people possessed a higher level of income and tended to save more money in banks, and thus banks could provide offer more credit to the private sector.

\section{Variance decompositions analysis}

To investigate the role of the financial sector in poverty alleviation, the study then used Variance Decomposition Analysis (VDA). Specifically, VDA is adopted to measure and forecast the error variance of a variable, or how the size of differences before and after shocks, both coming from the variable itself as well as other variables. By using VDA, the study can provide a description of the influence of the financial sector through the variables of money supply (LM2) and the ratio of private credit (CR) on the poverty eradication (LPOV). The findings of the VDA are reported in Table 2. The study's results show that the largest contribution to the poverty variable was the variance in poverty (LPOV) itself.

As observed shown in Table 2, the changes in the variation of poverty very much depend on the

Table 2: Findings of the Variance Decomposition Analysis

\begin{tabular}{|c|c|c|c|c|c|c|}
\hline \multirow{2}{*}{ Period } & \multicolumn{9}{|c|}{ Explained by Shock in: } \\
\cline { 2 - 7 } & LPOV & \multicolumn{3}{|c|}{ Model 1: Supply of Money } & \multicolumn{3}{c|}{ Model 2: Private Credit Ratio } \\
\hline 2 & 64.065 & 25.649 & 10.285 & 98.925 & 0.836 & 0.239 \\
\hline 4 & 60.454 & 28.449 & 11.096 & 96.279 & 2.038 & 1.683 \\
\hline 6 & 57.950 & 28.727 & 13.322 & 94.010 & 2.108 & 3.882 \\
\hline 8 & 50.575 & 26.560 & 22.864 & 89.044 & 2.073 & 8.883 \\
\hline 10 & 46.431 & 18.056 & 35.513 & 80.410 & 2.320 & 17.269 \\
\hline 12 & 45.571 & 13.672 & 40.757 & 72.048 & 2.607 & 25,344 \\
\hline 14 & 48.515 & 12.325 & 39.160 & 66.638 & 2.648 & 30,713 \\
\hline 16 & 49.864 & 12.676 & 37.459 & 63.262 & 2.754 & 33,984 \\
\hline 18 & 50.062 & 13.005 & 36.933 & 61.549 & 2.904 & 35.546 \\
\hline 20 & 49.946 & 13.219 & 36.835 & 61.297 & 2.939 & 35.764 \\
\hline
\end{tabular}


variation in its owned lagged values, ranging from 49.95\% to $64.06 \%$ in Model 1, when the financial sector was measured by the money supply, and from $61.30 \%$ to $98.92 \%$ in Model 2, when the financial sector was measured by the credit ratio. The variations in poverty changes responded more to shocks in the money supply (between $25.65 \%$ to $26.56 \%$ ) than to shocks in economic growth (between $10.28 \%$ to $22.86 \%$ ) up to the $8^{\text {th }}$ year, but in the later period, year-10 onward, the shock in economic growth explained more variation (between $35.51 \%$ to $36.83 \%$ ) in the poverty level than to the shock in money supply (between $18.06 \%$ to $13.22 \%)$. These findings imply that to alleviate the poverty within a shorter period, stabilizing price level is one of the most strategic policies, while to alleviate poverty over a longer period, promoting economic growth is the most effective policy.

Furthermore, the findings from Model 1 were somewhat similar to the findings from Model 2. The variation in the poverty level up to the $4^{\text {th }}$ year period was explained more by the shocks in the credit ratio (from $0.84 \%$ to $2.04 \%$ ) as compared to shocks in economic growth (from $0.24 \%$ to $1.68 \%$ ). From the $6^{\text {th }}$ year onwards, poverty changes were explained more by the shocks to economic growth by $3.88 \%$ to $35.76 \%$ as compared to the explanation by the shocks to the credit ratio by $2.11 \%$ to $2.94 \%$ annually. These findings further imply that to eradicate poverty in a shorter period, providing financial resources to the private sector such as micro-enterprises has proven to be the most effective strategy for poverty reduction. In the long term, this would lead the economy to grow steadily and, in turn, would cause the poverty level to decline. These findings further confirm that the poverty level could be reduced through long-term economic growth realized by stabilizing price level and providing more funds to the private sector in the short run (Sehrawat and Giri 2016a, 2016b). Having a prudent monetary policy to promote sustainable economic growth is a necessary pre-requisite for poverty alleviation (Sasmal and Sasmal 2016).

\section{Impulse-response functions}

Impulse response functions (IRFs) provide a practical portrayal of the behaviour of time series data in response to various shocks in the estimated model (Kasim and Majid 2010). Differently put, IRFs trace the impact of a shock to the independent variables on the dependent variable. Shocks might not only occur directly on these variables, but they also lead to the influence of all the other variables in the model and show the duration of their existence in responding to the shocks.

Figure 1 provides the findings of the IRFs analysis, focusing on the response of a variable to the Cholesky one standard deviation innovation in the variable itself and other variables in the model for a period of 20 years. Figure 1 shows that the response of the poverty variable to the innovations in the money supply was positive up to period 4. However, during period 5 onwards, the poverty level responded negatively to shocks in the money supply. This indicates that over a long-term period, an increase in the money supply has a negative impact on poverty in Indonesia. A decrease in the amount of money circulation within the community nationwide with proper controls by the government causes the prices of the majority of goods and services in Indonesia to decline, thus resulting in increased consumer purchasing power and, therefore, enhances the level of household consumption. Consequently, this indicates that the poverty level has reduced in the country over the period of the study.

Furthermore, the response of poverty to shocks to economic growth fluctuated until the end period

Figure 1: Impulse Responses to Poverty and Financial Development

The Responses of Poverty to:

Money Supply

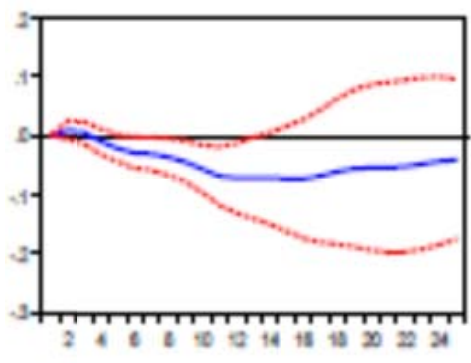

Credit Ratio

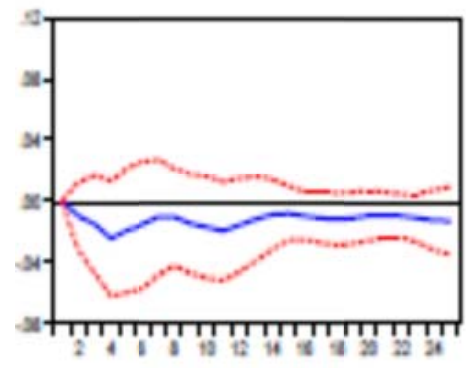

Economic Growth

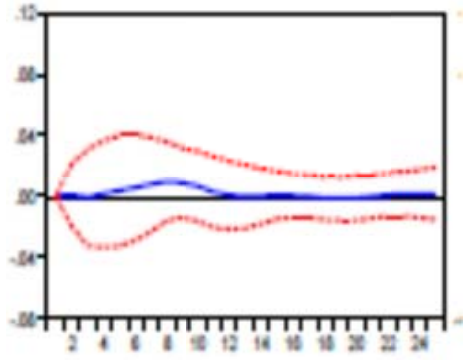


under study. Until the fourth period, the increase in economic growth led to poverty reduction, while during period 5 onwards, innovations in economic growth responded negatively to the poverty rate in the country. This finding further confirmed earlier findings that economic growth failed to promote the welfare of the poor, but instead widened the gap of income inequality (Sasmal and Sasmal 2016). Thus, to alleviate poverty, the government should design a pro-poor economic policy to promote economic development in the most populous Muslim country in the world.

Finally, the poverty rate consistently responded negatively to innovations in the ratio of private credit throughout the period of analysis. This finding further implied that the financial resources offered by the financial institutions in Indonesia have been mainly enjoyed by an upper-income group in the private sector and has been not transmitted into the lower income group, and thus widened income disparities. A relatively high interest rate in Indonesia with an average of $7.21 \%$ over the period $2005-2015$ compared to the neighbouring country of Malaysia with an average of $2.98 \%$ within the similar period (World Bank 2016) seemed to contribute to the negative response of the poverty level to changes in the ratio of private credit in Indonesia. These findings implied that providing financial assistance to the poorest segments of the population at a lower cost (Odhiambo 2009a) is an effective strategy to combat poverty in Indonesia nationwide.

\section{CONCLUSIONS AND POLICY IMPLICATIONS}

This study empirically explored the relationship between the financial sector, economic growth, and poverty reduction in Indonesia by using annual data from the period of 1980 to 2015. Several time series techniques, including Autoregressive Distributed Lag (ARDL), Granger causality, Impulse Response Functions (IRFs) and Variance Decomposition Analysis (VDA) were employed. Based on the ARDL approach, the study found that there was a long-run equilibrium between the financial sector, economic growth and poverty reduction in Indonesia, a finding similar to that of Sehrawat and Giri $(2016 a, 2016 b)$ in Asian economies. This implied that, in the long run, it is necessary for policy-makers to synergize economic policy, including monetary policy for poverty alleviation, with financial sector development and economic growth. The policy-makers should focus on poverty alleviation by encouraging the development of the financial sector and a pro-poor economic growth.
The results of the bivariate causality revealed that there was unidirectional causality between the money supply and poverty alleviation. This indicated that if the government wanted to alleviate poverty, the government should control the money supply to ensure price stability. An increase in price would further weaken the purchasing power of the society, especially the poor, who have lower incomes, thus causing the poorhousehold consumption level as well as their social welfare to decline. A unidirectional causality was also documented between poverty and the ratio of private credit. An increase in the poverty level caused the financial sector development to decline. Thus, to alleviate poverty, the government should design economic policy focused on encouraging an increase in investment that could lead to the development of the financial sector. Similarly, financial sector development could be promoted by increasing the use of credit as an alternative financing. Differently put, to accelerate the alleviation of poverty, the government needs to provide more credit facilities to the poor. Furthermore, this would lead to an expansion of the banking sector and other financial services (Sehrawat and Giri 2016a, 2016b). This is as stated by Uddin et al. (2012) that through the financial sector, the access and availability of credit for the poor could be promoted.

Furthermore, the study found bidirectional causality between poverty reduction and economic growth. This suggests that changes in economic growth Granger caused the changes in poverty level (Sasmal and Sasmal 2016). The economic growth would reduce the poverty rate, and an increase in the poverty level would reduce the income level of the society, thus causing the poverty level to increase. In fact, today in Indonesia, strong economic growth has helped in reducing poverty, but poverty reduction has been accompanied by an increase in income inequality. This is evidenced by an increase in the Gini coefficient ratio as a measure of the inequality from 0.30 in 2000 to 0.41 in 2013. This indicated that the economic development of Indonesia has failed to promote the welfare of the poor. Thus, pro-poor and pro-growth economic policies should be designed to promote economic growth with a lower poverty level. Economic growth should offer more job opportunities and promote labour-intensive investment. When the government spurs the growth of the real sector, the poverty level also reduced at the same time through new jobs creation and job opportunity expansion for the poor to increase their level of income.

Finally, to eradicate poverty in the country, it is very important for the government to provide more credit at a lower interest rate to the private sector, including micro-enterprises, thus leading the economy to grow 
over a long-term period, and in turn reduce the poverty level. Thus, the poverty level could be reduced through long-term economic growth realized by stabilizing price level and providing more funds to the private sector in the short run. Having a prudent monetary policy to promote sustainable economic growth is a necessary pre-requisite for poverty alleviation.

This study offers empirical evidence on the importance of the financial development-poverty reduction nexus in Indonesia. However, future studies might consider several areas to build upon to enrich the literature on this topic. This includes utilizing panel data covering the 34 provinces in the country and considering the wider aspect of macroeconomic policy variables in combating poverty in Indonesia.

\section{REFERENCES}

Abdullah, D.A. 1998. Money Growth Variability and Stock Returns: An Innovations Accounting Analysis. International Economic Journal 12 (4): 89-104.

Abosedra, S., Shahbaz, M. and Nawaz, K. 2016. Modeling Causality between Financial Deepening and Poverty Reduction in Egypt. Social Indicators Research 126 (3): 955-969.

Akinboade, O. A., and Kinfack, E. C. 2014. An Econometric Analysis of the Relationship between Millennium Development Goals, Economic Growth and Financial Development in South Africa. Social Indicator Research 118 (2): 775-795.

Bahmani-Oskooee, M. and Bohl, M. T. 2000. German Monetary Unification and the Stability of the German M3 Money Demand Function. Economics Letters 66 (2): 203-208.

Bappenas. 2014. Laporan Pencapaian Tujuan Pembangunan Milenium di Indonesia Tahun 2013. Jakarta: Bappenas.

Bappenas. 2017. Laporan Pencapaian Tujuan Pembangunan Millennium di Indonesia Tahun 2016. Jakarta: Bappenas.

Beck, T., Demirgüç-Kunt, A. and Levine, R. 2007. Finance, Inequality and the Poor. Journal of Economic Growth 12 (1): 27-49.

Central Bank of Indonesia. 2016. Statistik Ekonomi dan Keuangan Indonesia. Accessed in March 20, 2016, from http://www.bi.go.id.

Central Statistics Agency of Indonesia. 2011. Statistik Indonesia: Statistical Yearbook of Indonesia, 2010. Jakarta: BPS.

Central Statistics Agency of Indonesia. 2015. Statistik Indonesia: Statistical Yearbook of Indonesia, 1980-2015. Jakarta: BPS.

Central Statistics Agency of Indonesia. 2016. Statistik Indonesia: Statistical Yearbook of Indonesia, 2015. Jakarta: BPS.
Central Statistics Agency of Indonesia. 2017. Statistik Indonesia: Statistical Yearbook of Indonesia, 2016. Jakarta: BPS.

Dhrifi, A. 2015. Financial Development and the "GrowthInequality-Poverty" Triangle. Journal of the Knowledge Economy 6 (4): 1163-1176.

Enders, W. 1995. Applied Econometrics Time Series, USA: John Wiley and Sons, Inc.

Ewing, B. T., Forbes, S. M. and Payne, J. E. 2003. The Effects of Macroeconomic Shocks on Sector-Specific Returns. Applied Economics 35 (2): 201-207.

Ho, S. Y. and Odhiambo, M. 2011. Finance and Poverty Reduction in China: An Empirical Investigation. International Business Economic Research Journal 10 (8): 103-114.

Jalilian, H. and Kirkpatrick, C. 2005. Does Financial Development Contribute to Poverty Reduction?. Journal of Development Studies 41 (4): 636-656.

Kasim, S. and Majid, M. S. A. 2010. Impact of Financial Shocks on Islamic Banks: Malaysian Evidence during 1997 to 2007 Financial Crisis. International Journal of Islamic and Middle Eastern Finance and Management 3 (4): 291-305.

Laurenceson, J. and Chai, J.C.H. 2003. Financial Reform and Economic Development in China, Cheltenham: Edward Elgar.

Levine, R. 2005. "Finance and Growth: Theory and Evidence". Handbook of Economic Growth 1: 865-934.

Lütkepohl, H. and Poskitt, D.S. 1991. Estimating Orthogonal Impulse Responses via Vector Autoregressive Models. Econometric Theory 7 (4): 487-496.

Majid, M. S. A. and Kassim, S. H. 2009. Impact of the 2007 US Financial Crisis on the Emerging Equity Markets. International Journal of Emerging Markets 4(4): 341-357.

Majid, M. S. A. and Kassim, S. H. 2015. Assessing the Contribution of Islamic Finance to Economic Growth: Empirical Evidence from Malaysia. Journal of Islamic Accounting and Business Research, 6 (2), 292-310.

Majid, M. S. A. and Mahrizal. 2007. Does Financial Development Cause Economic Growth in the ASEAN-4 Countries? Saving and Development XXXI (4): 1-30.

Majid, M. S. A. and Yusof, R.M. 2009. Long-Run Relationship between Islamic Stock Returns and Macroeconomic Variables: An Application of the Autoregressive Distributed Lag Model. Humanomics 25 (2): 127-141.

Majid, M.S.A. 2008. Does Financial Development Matter for Economic Growth in Malaysia? An ARDL Bound Testing Approach. Journal of economic Cooperation 29 (1): 61-82.

Miled, K. B. H. and Rejeb, J. E. B. 2015. Microfinance and Poverty Reduction: A Review and Synthesis of Empirical Evidence. Procedia-Social and Behavioural Sciences 195: 705-712. 
Narayan, P. K. 2005. The Saving and Investment Nexus for China: Evidence from Cointegration Test. Applied Economics 37 (17): 1979-1990.

Odhiambo, N. M. 2009a. Financial Deepening and Poverty Reduction in Zambia: An Empirical Investigation. International Journal of Social Economics 37 (1): 41-53.

Odhiambo, N. M. 2009b. Finance-Growth-Poverty Nexus in South Africa: A Dynamic Causality Linkage. The Journal of Socio-Economics 38 (2): 320-325.

Odhiambo, N. M. 2010a. Is Financial Development a Spur to Poverty Reduction? Kenya's Experience. Journal of Economic Studies 37 (3): 343-353.

Odhiambo, N. M. 2010b. Finance-Investment-Growth Nexus in South Africa: An ARDL Bounds Testing Procedure. Economic Change Restructure 43 (3): 205-219.

Patrick, H. T. 1966. Financial Development and Economic Growth in Underdeveloped Countries. Economic Development and Cultural Change 14 (2): 174-189.

Perez-Moreno, S. 2011. Financial Development and Poverty in Developing Countries: A Causal Analysis. Empirical Economics 41 (1): 57-80.

Pesaran, M. H. and Shin, Y. 1998. Generalized Impulse Response Analysis in Linear Multivariate Models. Economics Letters 58 (1): 17-29.

Pesaran, M.H. and Pesaran, B. 1997. Working with Microfit 4.0: Interactive Econometric Analysis [Windows Version]. Oxford University Press.

Pradhan, R.P. 2010. The Nexus between Finance, Growth, and Poverty in India: The Cointegration and Causality Approach. Asian Social Science 6 (9): 114-122

Robinson, J. 1952. The Model of an Expanding Economy. The Economic Journal 62 (245): 42-53.

Samargandi, N., Fidrmuc, J. and Ghost, S. 2014. Financial Development and Economic Growth in an Oil-Rich Economy: The Case of Saudi Arabia. Economic Modelling 43: 267-278.

Sasmal, R. and Sasmal, J. 2016. Public Expenditure, Economic Growth and Poverty Alleviation. International Journal of Social Economics 43 (6): 604-618.
Sehrawat, M. and Giri, A. K. 2016b. Financial Development and Poverty Reduction: Panel Data Analysis of South Asian Countries. International Journal of Social Economics 43 (4): 400-416.

Sehrawat, M. and Giri, A.K. 2016a. Financial Development and Poverty Reduction in India: An Empirical Investigation. International Journal of Social Economics 43 (2): 106-122.

SESRIC. 2016. OIC Economic Outlook 2016. Transforming the Potentials into Impact. The Statistical, Economic, and Social Research and Training Centre for Islamic Countries. Turkey: Organization of Islamic Cooperation.

Shahbaz, M., Loganathan, N., Tiwari, A. K. and SherafatianJahromi, R. 2015. Financial Development and Income Inequality: Is there any Financial Kuznets Curve in Iran?. Social Indicators Research 124 (2): 357-382.

Sims, C. 1980. Comparison of Interwar and Postwar Business Cycles: Monetarism Reconsidered. American Economic Review: Papers and Proceedings 70 (2): 250-7.

Smajic, S., and Ermacora, S. 2007. Poverty amongst FemaleHeaded Households in Bosnia and Herzegovina: An Empirical Analysis. South East European Journal of Economics and Business 2(1): 69-88.

Statistical Year Book of Indonesia. 2014. Statistik Indonesia 2013: Jakarta: BPS.

Uddin, G. S., Kyophilavong, P. and Sydee, N. (2012). The Casual Nexus of Banking Sector Development and Poverty Reduction. International Journal of Economics and Financial Issues 2(3): 304-311.

Uddin, G. S., Shahbaz, M., Arouri, M. and Teulon, F. 2014. Financial Development and Poverty Reduction Nexus: A Cointegration and Causality Analysis in Bangladesh. Economic Modelling 36: 405-412.

World Bank. 2016. Domestic Credit to Private Sector Per GDP Ratio. http://data.worldbank.org. Accessed 23 March 2015.

Yusof, R. M., Kassim, S. H., Majid, M. S. A. and Hamid, Z. 2011. Determining the Viability of Rental Price to Benchmark Islamic Home Financing Products: Evidence from Malaysia. Benchmarking: An International Journal 18 (1): 69-85. 
Table A1: Findings of the stationarity tests

\begin{tabular}{|c|c|c|c|c|c|}
\hline \multirow{2}{*}{ Variable } & \multicolumn{2}{|c|}{ ADF Test } & \multicolumn{2}{|c|}{ PP Test } & \multirow{2}{*}{ Decision } \\
\hline & Level & 1st Difference & Level & 1st Difference & \\
\hline LPOV & -1.7317 & $-4.8002^{* * *}$ & -2.1032 & $-4.7652^{* * *}$ & Stationary \\
\hline $\mathrm{CR}$ & -2.1091 & $-4.1232^{* *}$ & -1.0400 & $-4.1751^{* *}$ & Stationary \\
\hline LM2 & -0.3124 & $-4.7655^{* * *}$ & -0.1054 & $-4.70982^{* * *}$ & Stationary \\
\hline LPDB & -2.1009 & $-4.5421 * * *$ & -1.5001 & $-4.7091^{* * *}$ & Stationary \\
\hline
\end{tabular}

Notes: ${ }^{* * *}$ and ${ }^{* *}$ indicate significance at the $1 \%$ and $5 \%$ levels. The ADF and PP tests were based on the model with intercept and trends.

Table A2: Findings of the ARDL models

\begin{tabular}{|c|c|c|c|}
\hline $\begin{array}{l}\text { Dependent/Independent } \\
\text { Variable }\end{array}$ & Optimal Lag-Length & F-statistics & Decision \\
\hline LPOV/LM2,LPDB & $6,5,6$ & $4.2022^{*}$ & Cointegrated \\
\hline LM2/LPOV,LPDB & $2,3,3$ & $7.1403^{* * *}$ & Cointegrated \\
\hline LPDB/LM2,LPOV & $3,3,2$ & $6.0986^{* * *}$ & Cointegrated \\
\hline LPOV/CR,LPDB & $6,5,5$ & $5.9876^{* *}$ & Cointegrated \\
\hline CR/LPOV,LPDB & $1,3,2$ & $9.6578^{* * *}$ & Cointegrated \\
\hline LPDB/CR,LPOV & $5,5,6$ & $6.9932^{* * *}$ & Cointegrated \\
\hline
\end{tabular}

Notes: ${ }^{* * *},{ }^{* *}$ and ${ }^{*}$ indicate significance levels at the $1 \%, 5 \%$, and $10 \%$, respectively. The critical value bounds are taken based on Narayan (2005) (case II: restricted intercept and no trend, with the number $k=2$ ) is 4.94 to 6.02 at a rate of $1 \%$; 3.47 to 4.33 on the level $5 \%$ and 2.84 to 3.62 at the $10 \%$ level. 